\title{
セラミックス半導体の交流伝導シミュレーション
}

\author{
岡 野一雄 \\ (小山職業訓練短期大学校電子技術科, 323 杤木県小山市横倉三竹 612-1)
}

\section{Simulation of a.c. Conduction in Ceramic Semiconductors}

\author{
Kazuo OKANO \\ $\left(\begin{array}{cc}\text { Department of Electronic Devices Technology, Oyama Vocational Training College, } \\ 612-1 \text {, Yokokura Mitake, Oyama-shi, Tochigi } & 323\end{array}\right)$
}

\begin{abstract}
The frequency dependence of electrical conductivity of ceramic semiconductors was simulated with a computer. An equivalent circuit was proposed based on the microstructure model, the charge distribution model, and the energy band model. Using an equivalent circuit, the simulation was achieved under the following conditions on the density of trap level $\left(N_{s}\right)$ and impurity concentration $\left(N_{p}\right)$.

(1) The homogeneous microstructure; $N_{s}$ and $N_{p}$ are uniform for each grain and grain boundary.

(2) The inhomogeneous microstructure; $\log N_{s}$ and $\log N_{p}$ have the normal distribution with the standard deviation of 0.3.

As a result of simulation, a remarkable difference was shown between the above two cases. It was found that the distribution of microstructure-dependent factors such as impurity concentration must be considered to discuss the electrical properties of ceramic semiconductors.

[Received May 25, 1989 ; Accepted July 14, 1989]
\end{abstract}

Key-words : Computer simulation, a.c. conduction, Ceramic semiconductor, Equivalent circuit, Impurity concentration, Trap level density

\section{1. 緒 言}

セラミックスを均質化する研究が進められている が1), 本来セラミックスは多数の粒子と粒界からなる複 合体であるため, 少なくとも現状のセラミックスを均質 物質として扱うことは困難である. 特にセラミックス半 導体の電気伝導特性は, 粒子の形状や寸法, 粒界部の卜 ラップレベルの濃度, 粒子内の結晶欠陥の濃度等の微構 造に大きく依存する．このような微構造を均一化するこ とは非常に難しい，そこで，セラミックス半導体を扱う 場合には，その不均一性を考慮して検討を進める必要が あると考えている.

本報では, 微構造の不均一性として, 粒界部のトラッ プレベルの濃度と粒子の不純物濃度の不均一性だけを取 り上げた．各粒子の不純物濃度が均一である場合と不均 一である場合のそれぞれについて，電気伝導度の周波数 依存性を等価回路を用いてコンピューターシミュレー ションし,不均一性を考慮することの必要性を検討した。

\section{2. モデル化とシミュレーション}

セラミックス半導体は単結晶からなる粒子と，粒子と 粒子の接合部である粒界の複合体であるため, その微構 造は図1(a) のようにモデル化できる，粒界にはダング リングボンド等に基づいてトラップレベルが高濃度に存 在し，この濃度を $N_{s}$ とする. また, 粒子はアクセプター
濃度が $N_{\mathrm{P}}$ の $\mathrm{p}$ 型半導体であるとすると, 粒子内のホー ルは粒界のトラップレベルにトラップされ，粒界近傍に は図 1(b) に示すような電荷分布が形成される.ここで, 粒界にトラップされたホールの濃度は $N_{\mathrm{s}}$ であるから, 粒界近傍に形成される空乏層の幅 $W$ は

$$
W=N_{\mathrm{s}} / N_{\mathrm{P}}
$$

となる．このような空乏層内には電界が発生し，その結 果として粒界近傍には, 図1(c) に示すようなシンメト リショットキバリヤが形成され，そのバリヤハイト $\phi_{\mathrm{B}}$ は

$$
\phi_{\mathrm{B}}=N_{\mathrm{s}}{ }^{2} e / 2 \varepsilon_{0} \varepsilon_{\mathrm{s}} N_{\mathrm{P}}
$$

となる. したがって, その等価回路は図 2 に示すように, 粒界近傍にキャパシタンス $C_{\mathrm{GB}}$ と抵抗 $R_{\mathrm{GB}}$ が並列に接 続され, 更にこの $C_{\mathrm{GB}}$ と $R_{\mathrm{GB}}$ に粒子内の抵抗 $R_{\mathrm{G}}$ が接続 された回路となる。この図において破線は粒界を示し, 粒子と粒界に対応した位置に等価回路の回路素子を示し てある.ここで, 空乏層の幅を $W$, 粒界の面積を $S$, セラミックス半導体の比誘電率を $\varepsilon_{\mathbf{s}}$, 真空中の誘電率 を $\varepsilon_{0}$ とすると, 粒界近傍のシンメトリショットキバリ ヤに基づくキャパシタンス $C_{\mathrm{GB}}$ は

$$
C_{\mathrm{GB}}=\varepsilon_{0} \varepsilon_{\mathrm{S}} S / W
$$

となる.

また（1）式より $W=N_{\mathrm{s}} / N_{\mathrm{P}}$ であるから（3）式は $C_{\mathrm{GB}}=\varepsilon_{0} \varepsilon_{\mathrm{S}} S N_{\mathrm{P}} / N_{\mathrm{s}}$ 
となる。

一方, 粒界近傍に形成されたシンメトリショットキバ リヤに基づく抵抗成分 $R_{\mathrm{GB}}$ は

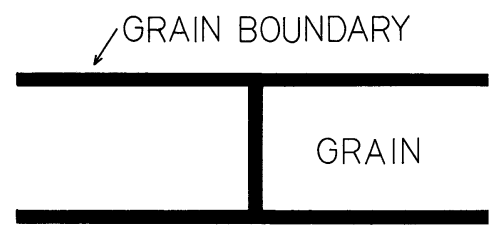

(a)

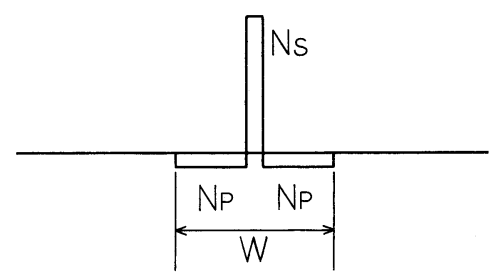

(b)

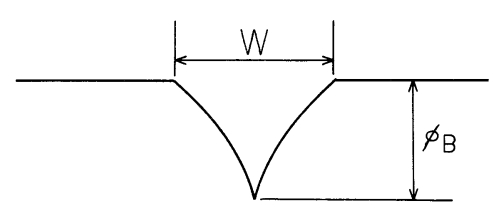

(C)

Fig. 1. Sketch of models in ceramic semiconductor. (a) Model for microstructure. (b) Charge distribution around a grain boundary. $N_{\mathrm{s}}$ : Trap level density, $N_{\mathrm{P}}$ : Acceptor concentration. (c) Energy band structure. $W$ : Deplation layer width, $\Phi_{\mathrm{B}}$ : Schottky barrier hight.

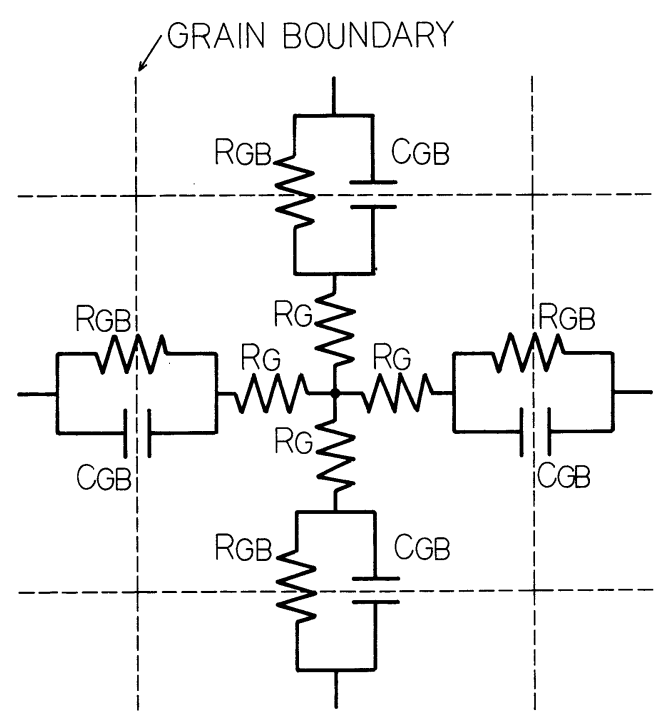

Fig. 2. Equivalent circuit in ceramic semiconductor. $R_{\mathrm{GB}}$ : Resistance based on the Schottky barrier, $C_{\mathrm{GB}}$ : Capacitance based on the Schottky barrier, $R_{\mathrm{G}}$ : Resistance within a grain .

$$
R_{\mathrm{GB}}=R_{0} \exp \left(\phi_{\mathrm{B}} e / k T\right)
$$

であり,この式に (2) 式を代入して, シンメトリショッ トキバリヤの抵抗成分 $R_{\mathrm{GB}}$ は

$$
R_{\mathrm{GB}}=R_{0} \exp \left(e^{2} N_{\mathrm{s}}{ }^{2} / 2 \varepsilon_{0} \varepsilon_{\mathrm{s}} k T N_{\mathrm{P}}\right)
$$

となる.

また，この等価回路における粒子の抵抗成分 $R_{\mathrm{G}}$ は， $R_{\mathrm{GB}} \gg R_{\mathrm{G}}$ であると考え，本報では無視した.

このような等価回路を用いて交流伝導度の周波数依存 性についてシミュレーションを行った. シミュレーショ ンにあたっては, 図 2 に示す回路において粒子が縦横に それぞれ 10 個, すなわち 100 個の粒子が 2 次元的に配 列した回路を用いた. また, 本報での交流伝導度は, シ ンメトリショットキバリヤのコンダクタンスを $G_{\mathrm{GB}}$, サ セプタンスを $B_{\mathrm{GB}}$ とし，アドミタンス $Y_{\mathrm{GB}}$ の絶対値, すなわち $\left|Y_{\mathrm{GB}}\right|=\left|G_{\mathrm{GB}}+j B_{\mathrm{GB}}\right|$ から求めた.

本報では微構造の不均一性として, トラップ濃度 $N_{\mathrm{s}}$ とアクセプタ濃度 $N_{\mathrm{P}}$ だけを扱っている.したがって, 微構造が均一なモデルに対しては, トラップ濃度とアク セプタ濃度のそれぞれを定数 $N_{\mathrm{s} 0}, N_{\mathrm{P} 0}$ とした. 一方, 不均一性を考慮したモデルでは, トラップ濃度とアクセ プタ濃度の平均値として上述の $N_{\mathrm{s} 0}, N_{\mathrm{P} 0}$ を用い, その 分布は $N_{\mathrm{s}}, N_{\mathrm{P}}$ の対数 $\left(\log N_{\mathrm{s}}\right.$ と $\left.\log N_{\mathrm{P}}\right)$ を正規分布さ せてそれぞれの標準偏差を 0.3 としてシミュレーション を行った。

\section{3. 結果と考察}

図 3 に周波数 $\mathrm{f}$ 之電気伝導度 $\sigma$ の関係をそれぞれ対 数で現した場合のシミュレーション結果を示す.この図 において実験 $(\mathrm{A})$ はトラップ濃度とアクセプタ濃度が

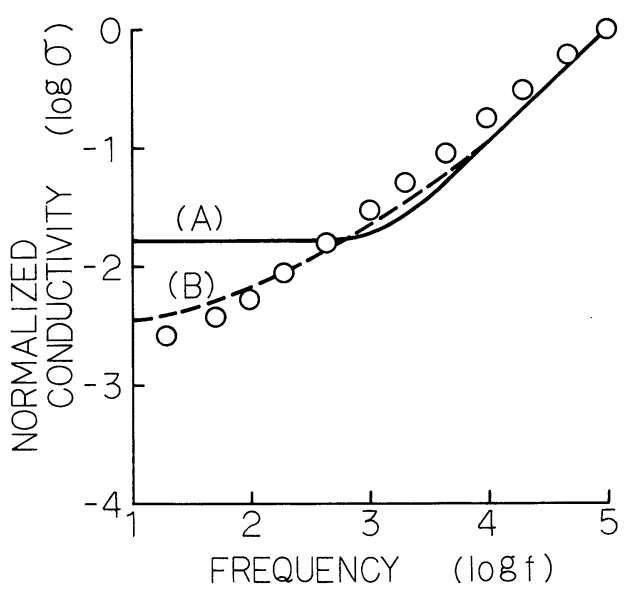

Fig. 3. Simulated result for frequency dependence of electrical conductivity of ceramic semiconductor. (A) : Trap level density and acceptor concentration are uniform. (B) : Trap level density and acceptor concentration are not uniform for each grain and grain boundary. $\bigcirc$ : Measured values on $\mathrm{SiC}$ ceramics. 
すべての粒子，粒界部で均一であると考えた場合の結果 であり, 破線 (B) はトラップ濃度とアクセプタ濃度に 不均一性を考慮した結果である.また，図中のプロット は，代表的なセラミックス半導体である $\mathrm{SiC}$ 焼結体に 関する実測值である2). なお，これらのシミュレーショ ン結果及び実測值は, $10^{5} \mathrm{HZ}$ での電気伝導度で規格化 してある。

セラミックス半導体の周波数依存性は, 低周波数側で は, 粒界近傍に形成されたシンメトリショットキバリヤ の抵抗成分 $R_{\mathrm{GB}}$ を流れる電流 $I_{\mathrm{R}}$ が支配的となるため, 電気伝導度は周波数に無関係で $\partial \log \sigma / \partial \log f=0$ と なっている. 一方, 高周波数側では $I_{\mathrm{R}}$ に比ベキャパシ タンス $C_{\mathrm{GB}}$ を流れる電流 $I_{\mathrm{c}}$ が支配的となるため, 電気 伝導度は周波数に比例し, $\partial \log \sigma / \partial \log f=1$ となっ ている. ところが, 不均一性を考慮した場合には周波数 を高くするに従って徐々に周波数依存性は大きくなって いるが，周波数範囲 4 析にわたって $\partial \log \sigma / \partial \log$ $f \neq 0$ かつ $\partial \log \sigma / \partial \log f \neq 1$ の領域が現れた.

このような不均一性を考慮したシミュレーション結果
は, 実測值において $\partial \log \sigma / \partial \log f \neq 0, \partial \log \sigma / \partial$ $\log f \neq 1$ の領域が 5 桁にもわたって現れることとよい 一致を示している.このような現象が不均一性に基づく ものであるか否かについてはさらに検討を必要とする が，少なくともセラミックス半導体の電気伝導を扱う場 合には, その不均一性を考慮する必要があると考えられ る.

\section{4. 総 括}

セラミックス半導体をモデル化し, 交流伝導度の周波 数依存性についてシミュレーションを行った.この結果, 各粒子, 粒界のアクセプタ濃度とトラップ濃度が均一で ある場合と不均一である場合では, その結果に大きな差 異が現れた. したがって, セラミックス半導体の電気物 性を検討する際には, セラミックスの微構造の不均一性 を考慮する必要があることが明らかになった。

\section{文 献}

1) セラミックス, 22, 1023-72 (1987).

2) 岡野一雄, 飯田治久, 表面科学, 9, 362-67 (1988). 